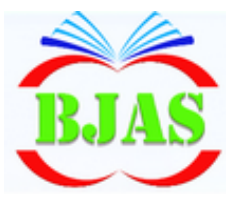

Available online at: http//bjas.bajas.edu.iq

College of Agriculture, University of Basrah

DOi:10.21276/basjas

ISSN 1814 - 5868 Basrah J. Agric. Sci., 32(Spec Issue): 140-152, 2019

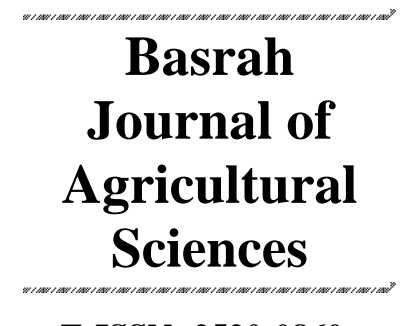

E-ISSN: 2520-0860

\title{
A Comparative Study of Feeding of Three Fish Species in the Southern Part of Al-Chibayish Marsh, Iraq
}

\author{
Osamah, A. Salih', Adel, Y. Al-Dubakel ${ }^{2 *}$ \& Jasim, M. Abed ${ }^{3}$ \\ ${ }^{1}$ Directory of Basrah Agriculture, Ministry of Agriculture, Iraq \\ ${ }^{2}$ Unit of Aquaculture, College of Agriculture, ${ }^{3}$ Department of Fisheries and Marine \\ Resources, College of Agriculture, University of Basrah, Iraq \\ *Corresponding author e-mail: aaldubakel@yahoo.com
}

Received 29 April 2019; Accepted 24 June 2019; Available online 18 September 2019

\begin{abstract}
Three species of fish Tigris asp (Leuciscus vorax) locally named " Shilluk "and Abu mullet (Planiliza abu) locally named "Khushani" and Blue tilapia (Oreochromis aureus) were collected from the Southern part of the Al-Chibayish marsh to study the composition of its natural food during the period from February 2014 to January 2015. Each species was divided into two-length group (1 and 2). Fishes consisted high percentage of Tigris asp food for both length groups, which reached $50 \%$ and $68 \%$ respectively. In contrast, sand and mud were of great importance in the food of Abu mullet that comprise $41 \%$ and $40 \%$ for the two length groups, respectively. The aquatic plant were most important in the food of blue tilapia at percentage of $56 \%$ and $50 \%$ for the two length groups, respectively. The highest feeding intensity (point/fish) reached by Tigris asp (11.30 and 13.50) during spring, for Abu mullet (10.52 and 8.08) during summer and autumn, whereas for Blue tilapia blue reached (14.82 and 12.66) in the spring and winter for the two length groups, respectively. However, feeding activity values differed according to month. The three species of fish showed a different specialization in the selection of their food components. The small individuals of the Tigris asp were narrowly specialized in food $(0.27)$ while the large individuals were highly specialized (0.25), whereas Abu mullet and Blue tilapia showed narrow specialization (0.42 and 0.37$)$ and $(0.32$ and 0.32$)$ for the two length groups respectively.
\end{abstract}

Keywords: Leuciscus vorax, Planiliza abu, Oreochromis aureus, Natural food, IRI.

\section{Introduction}

The study of food provides researchers with a lot of information about the environment of the individual (Bagenal \& Tesch, 1978). Identification of fish food components is important because fish are an important component of the food chain in aquatic systems. The study of the dietary habits and relationships of fish is of great importance in the study of fish populations, since the knowledge of food interaction between species is an important factor in 
understanding the nature of population and is an integral part of the study of the fish communities (Gysels et al., 1997; Liem, 1984). Food relations in fish vary depending on species adaptations, which may be simple or complex and thus occupy different levels in the food chain at different stages of their life history that influenced by certain environmental characteristics and vary according to seasons (Hurst \& Conover, 2001).

The Tigris asp (Leuciscus vorax) is a native and highly commercial cyprinid species inhabitıng Euphrates-Tigris Basin in Turkey, Syria and Iraq (Duman \& Gül, 2013). Tigris asp locally named "Shilluk".

Hussein et al. (1991) indicates that Tigris asp considered carnivorous fed on fish, benthic molluscs and large crustaceans, which are important food for Tigris asp in the Garmat Ali River. Hussein \& AL-Kanaani (1993) showed that Tigris asp intensity of feeding in Al-Hammar marches reached its peaked during May and its lowest was in January. While Hussain \& Ali (2006) showed that, the food of Tigris asp in Al Hammer Marsh consisted of fish, aquatic insects and crustacean. While its food in the eastern part of the Al-Hammar marches after rehabilitation consisted only of fish and crustaceans (Hussain et al., 2009). Tigris asp in the Garmat Ali River fed on 55.33\% fish, $22.51 \%$ crustaceans and $13.72 \%$ insects (Lazem, 2009).

Abu mullet (Planiliza $a b u$ ) is a native freshwater species of Iraq and neighbouring countries, (Coad, 2017 and Birecikligil et al., 2017). Abu mullet locally named "Khushani". Al-Malaika et al. (1977) noted that food is limited to phytoplankton, while Barak (1978) study feed in the Al-Saqlawiyah water fountain and noted the presence of animal food in the gizzard and intestines.
Islam \& Khalaf (1982) showed the feeding pattern of $\mathrm{Abu}$ mullet in the Rashdiyah Reservoir and found that its feeding peak at 6 a.m. and at 9 p.m. Ahmad \& Hussian (1982) studied Abu mullet feeding in Salihyia River. While Naama \& Muhsen (1986) pointed out that the main food of Abu mullet is the algae attached to the grains of sand, and it stops feeding during the night.

Blue tilapia (Oreochromis aureus) is an introduced fish which was recorded with Tilapia zillii (=Coptodon zillii) from the main outfall drain in Basrah (Mutlak \& Al-Faisal, 2009).

Few local studies were carried out on the feeding of Blue tilapia (Oreochromis aureus) such as study of Khalifa (2017), but many of the worldwide studies showed that this fish considered herbivores including the study of Noble (1989). While other previous studies shown, that it is detritivores the including study of Mallin (1985).

The present study aims to compare the feeding habits of three species of fish, i.e. Tigris asp (Leuciscus vorax) locally called "Shilluk", Abu mullet (Planiliza abu) locally called "Khushani" and Blue tilapia (Oreochromis aureus) locally called "Hammer" in the southern part of AlChibayish marsh within the scope of the food specialization of these species.

\section{Materials \& Methods}

The sampling area is located east of the AlChibayish District between the latitude of $47^{\circ}$ 05 '00.9 "east and the latitude $30^{\circ} 58^{\prime}$ '24.4" North. This region locally called "Abu Julaneh" and it is about $7 \mathrm{~km}$ east of AlChibayish district (Fig. 1).

In this region, many plants exist such as common reed Phragmites australis and cattail Typha sp. and hornwort Ceratophyllum demersum. 


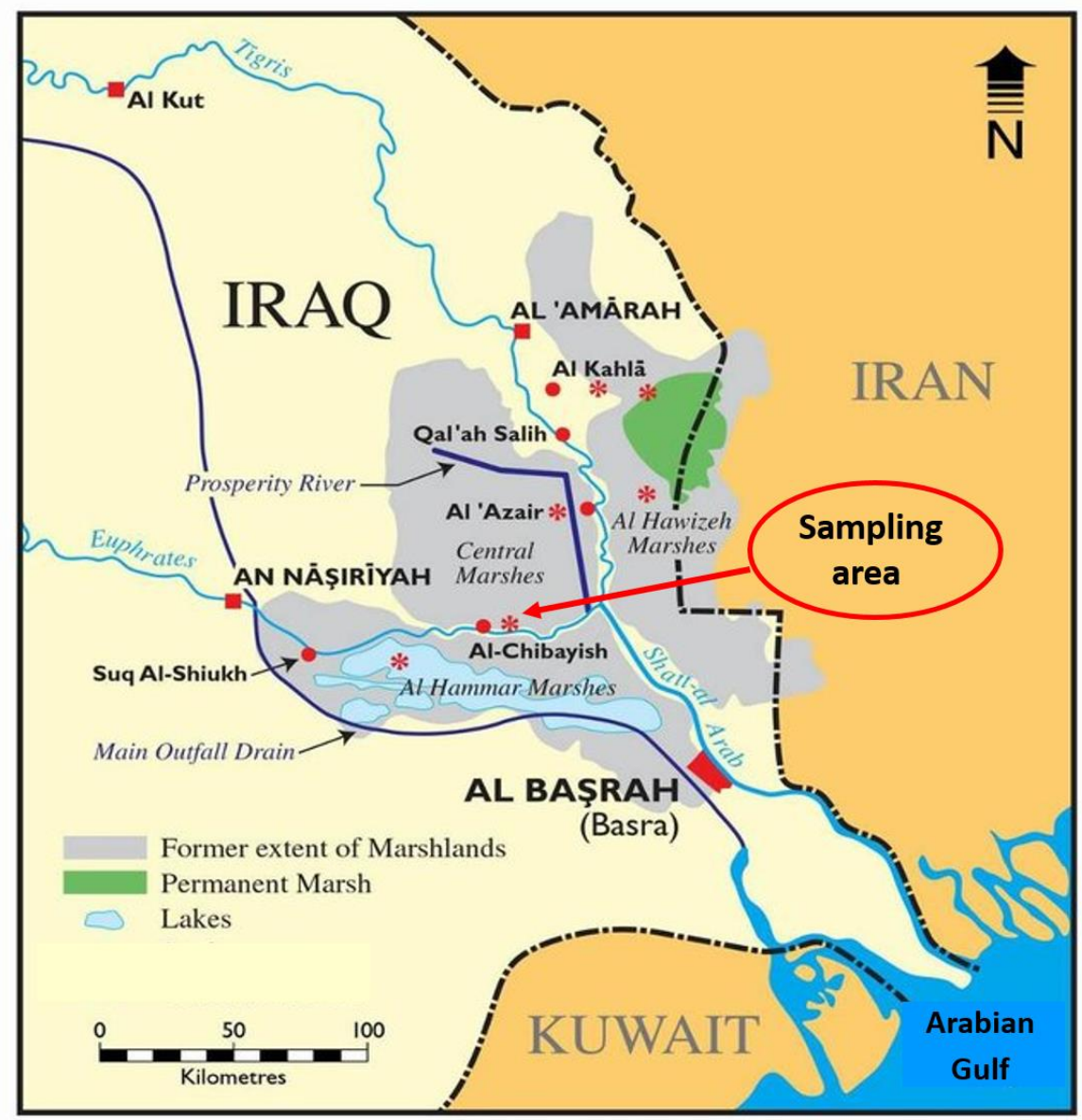

Fig.(1): Map of southern Iraq showing Al- Chibayish marshes and sampling area.

Fishes were collected by different sizes and fishing nets and electrofishing for the period from February 2014 to January 2015. Fishes were divided in the laboratory after measuring the length total weight into two length groups (Table 1). The Tigris asp divided into larger than and smaller or equal to $300 \mathrm{~mm}, \mathrm{Abu}$ mullet to larger than and smaller or equal to $100 \mathrm{~mm}$, blue tilapia to larger than and smaller or equal to $150 \mathrm{~mm}$ to complete the required measurement.

Table (1): Numbers and length groups for three species.

\begin{tabular}{lcccc}
\hline Species & $\begin{array}{c}\text { Small } \\
\text { individuals } \\
\text { group (mm) }\end{array}$ & No. & $\begin{array}{c}\text { Large individuals } \\
\text { group (mm) }\end{array}$ & No. \\
\hline Leuciscus vorax & $\leq 300$ & 227 & $>300$ & 117 \\
\hline Planiliza abu & $\leq 100$ & 508 & $>100$ & 706 \\
\hline Oreochromis aureus & $\leq 150$ & 270 & $>150$ & 309 \\
\hline
\end{tabular}


Fishes were dissected, the gastrointestinal tract removed, and the anterior part was cut to represent the stomach of Tigris asp, both Abu mullet and Blue tilapia, where the contents of the gizzard and the thin part of the intestine were examined (Al-Shamma'a et al., 2012). The stomach was isolated from the gastrointestinal tract its content were emptied into a petri dish and examined with dissecting microscope of $10 \mathrm{X}$ and $40 \mathrm{X}$ magnification also at $450 \mathrm{X}$ with the compound microscope for food item identification. Edmondson (1966) was used to classify food items. Three methods were used for analysing food components according to the food nature of the studied species. Weight (W) method used for Tigris asp while points (P) method used for Abu mullet and Blue tilapia beside the frequency of occurrence $(C)$ method for the three species according to Hyslop (1980) and Hansson (1998).

The index of relative importance (\% IRI) was calculated according to the Jutagate (2005) equation for the species with distinguishable stomach (Tigris asp):

$\% \mathrm{IRI}=(\% \mathrm{~N}+\% \mathrm{~W}) \% \mathrm{~F} / \sum(\% \mathrm{~N}+\% \mathrm{~W}) \%$ F x 100

While the index of relative importance was calculated according to the Stergiou (1988) equation for the species with undistinguishable stomach (Abu mullet and Blue tilapia):

$$
\% \mathrm{IRI}=(\% \mathrm{P}+\% \mathrm{~F}) / \sum(\% \mathrm{P}+\% \mathrm{~F}) \times 100
$$

Where

$\% \mathrm{~N}=$ Numerical percentage

$\% \mathrm{~W}=$ Weight percentage

$\% \mathrm{~F}=$ Frequency percentage

$\% \mathrm{P}=$ Points percentage
The feeding intensity and activity were calculated according to the Gordan (1977) equations:

Feeding Intensity $=\sum$ of fullness degree/ No. of fed fish

Feeding Activity $=$ (No. fed fish $/$ No. examined fish) $\times 100$

Niche breadth for the three species and the two length groups was calculated according to the Hurlbert,(1978) Krebs,(1999) equations:

$\mathrm{B}_{\mathrm{i}}=1 /(\mathrm{n}-1)\left[1 /\left(\mathrm{j} \sum{ }_{\mathrm{ig}} \mathrm{P}^{2}-1\right]\right.$

Where

$\mathrm{B}_{\mathrm{i}}=$ Niche breadth

$\mathrm{n}=$ No. food items

$\mathrm{P}=$ total consumed food items

The Niche breadth ranged from Bi values vary from 0 (species consume a single item) to 1 (species exploits available items in equal proportion), high (>0.6), intermediate $(0.4-0.6)$ or low $(<0.4)$ according to Novakowski et al. (2008).

\section{Results}

\section{Index of relative importance (IRI)}

Fig. (2A) showed the monthly changes in the percentage values for the index of relative importance of food components for small individuals of Tigris asp. The fish component predominated in most months of the study in the food of small individuals and reached 73\% in July, shrimp came secondly as the highest monthly percentage recorded in April ( $50 \%$ ), followed by aquatic insects and their larvae which recorded in all months except July and reached 52\% in December. Unspecified items were observed in most study months with highest value in August (11\%). 
In addition, the fish component ranked firstly in terms of importance in the food of large individuals of $L$. vorax and achieved distinguish dominant in all months of the study. The highest contribution was recorded in December by $83 \%$, while the shrimp component recorded at varying rates during the study period, in October reached 33\% Aquatic insects and their larvae recorded modest proportions, with the highest percentages of importance being $12 \%$ in August. The unspecified items were observed in three months only and were higher in August (8\%), no large Tigris asp individuals collected during September and November (Fig. 2B).

Fig. (3A) showed that organic detritus obtained the highest relative importance index for the food of small Abu mullet by $90 \%$ in July. Aquatic plants were contributed by $50 \%$ in November, algae $39 \%$ in December, and diatoms 34\% during August.

The organic detritus form the first importance in the food of large individuals of Abu mullet in terms of relative importance index, with a monthly contribution of $95 \%$ during July, while diatoms constituted $43 \%$ in

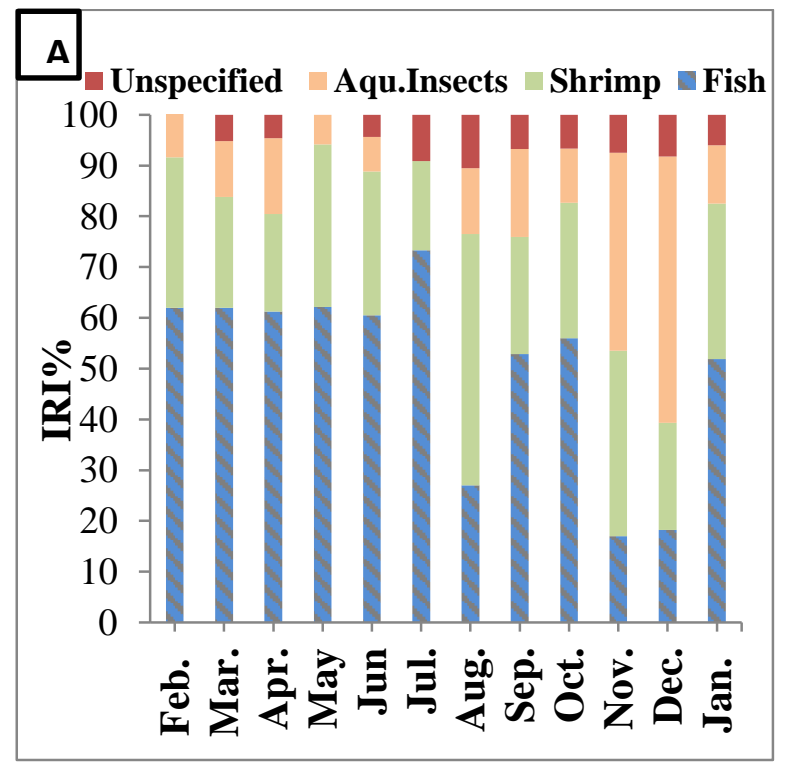

November, algae $39 \%$ in December and aquatic plants $30 \%$ in November (Fig. 3B).

The monthly changes in percentage values of the relative importance index of small Blue tilapia Fig. 4A. Aquatic plants recorded a clear monthly dominance, with the highest percentage of importance of $74 \%$ in April. Algae ranked second in their monthly contribution to the food of small individuals accounted for $28 \%$ in February and May, and diatoms contributed with varying monthly rates, the highest of which was $20 \%$ in November, while the highest monthly contribution of organic detritus was $12 \%$ in September and November.

The relative importance index of large Blue tilapia (Fig. 4B) showed monthly changes in percentage values of the relative importance index. Aquatic plants were the main components, which recorded in all months with a highest monthly importance of $68 \%$ in September. Algae was the second highest item of monthly importance and was $48 \%$ higher in October. Diatoms contributed in varying percentages and recorded the highest percentage $(21 \%)$ in November and the

Fig. (2): Monthly changes in Index of relative importance (IRI) for small (A) and large (B) individuals of Tigris asp.

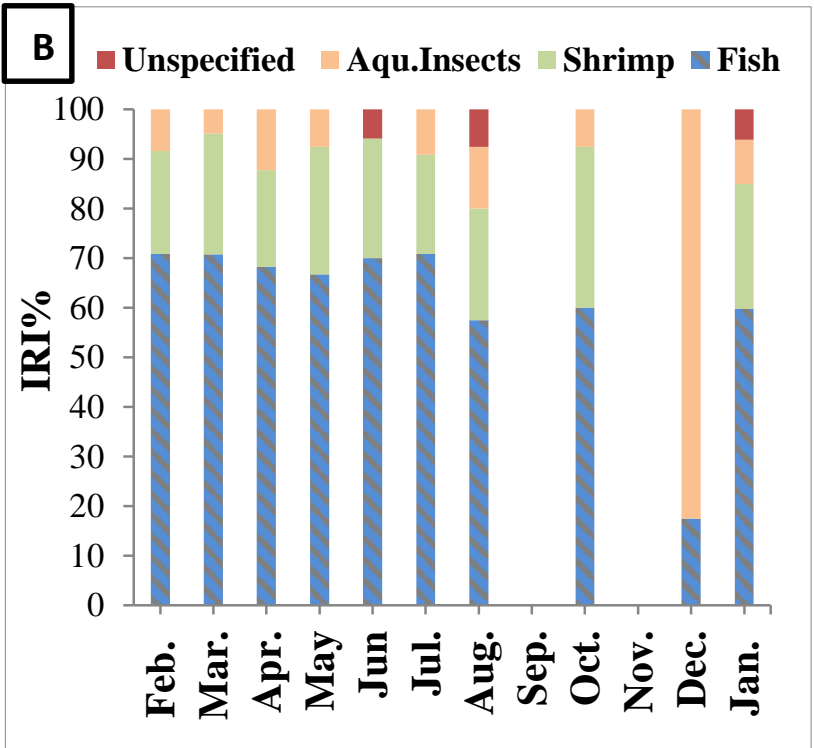


Salih et al. / Basrah J. Agric. Sci., 32 (Special Issue): 140-152, 2019

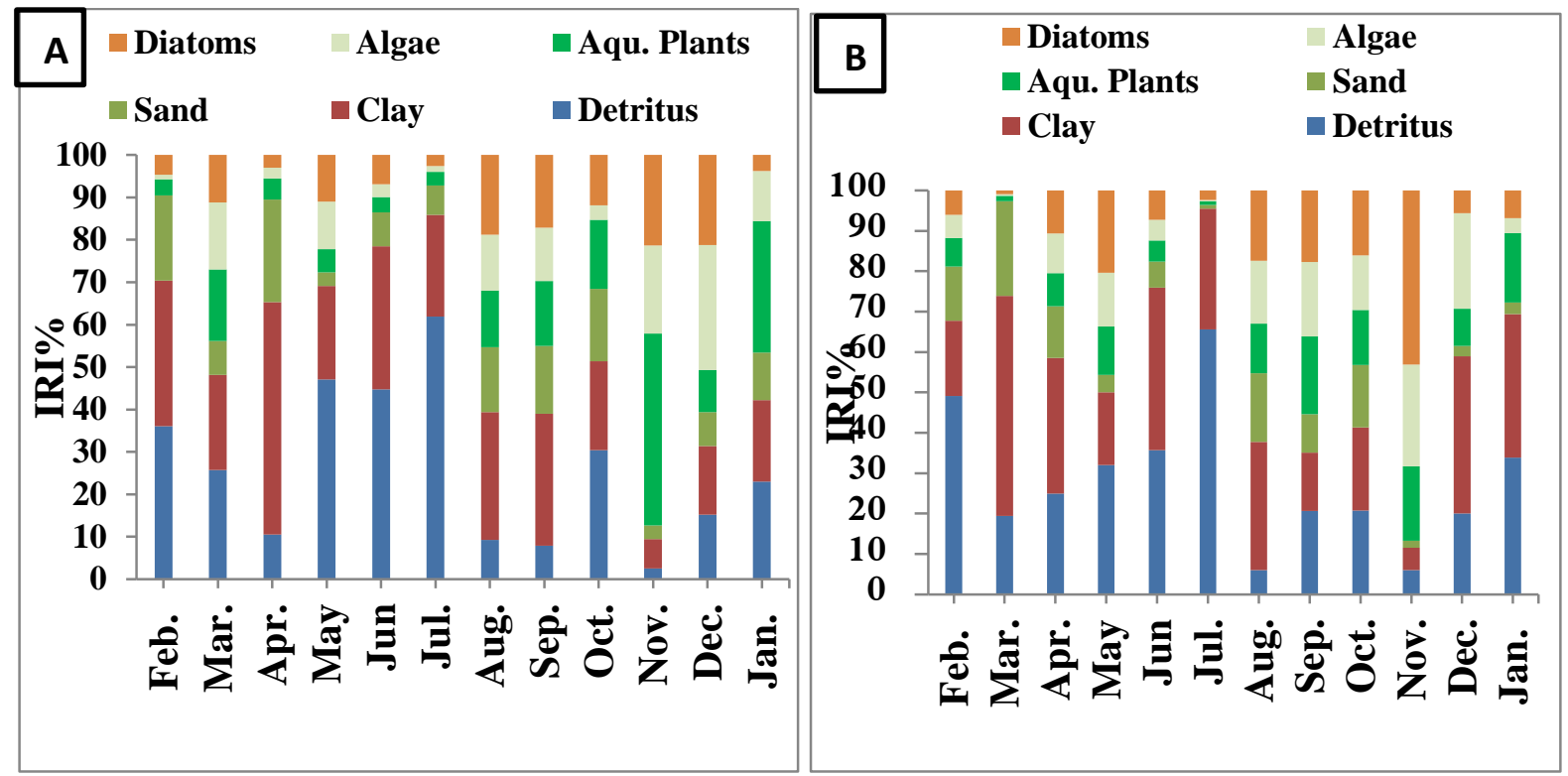

Fig. (4): Monthly changes in Index of relative importance (IRI) for small (A) and large (B) individuals of Abu mullet.

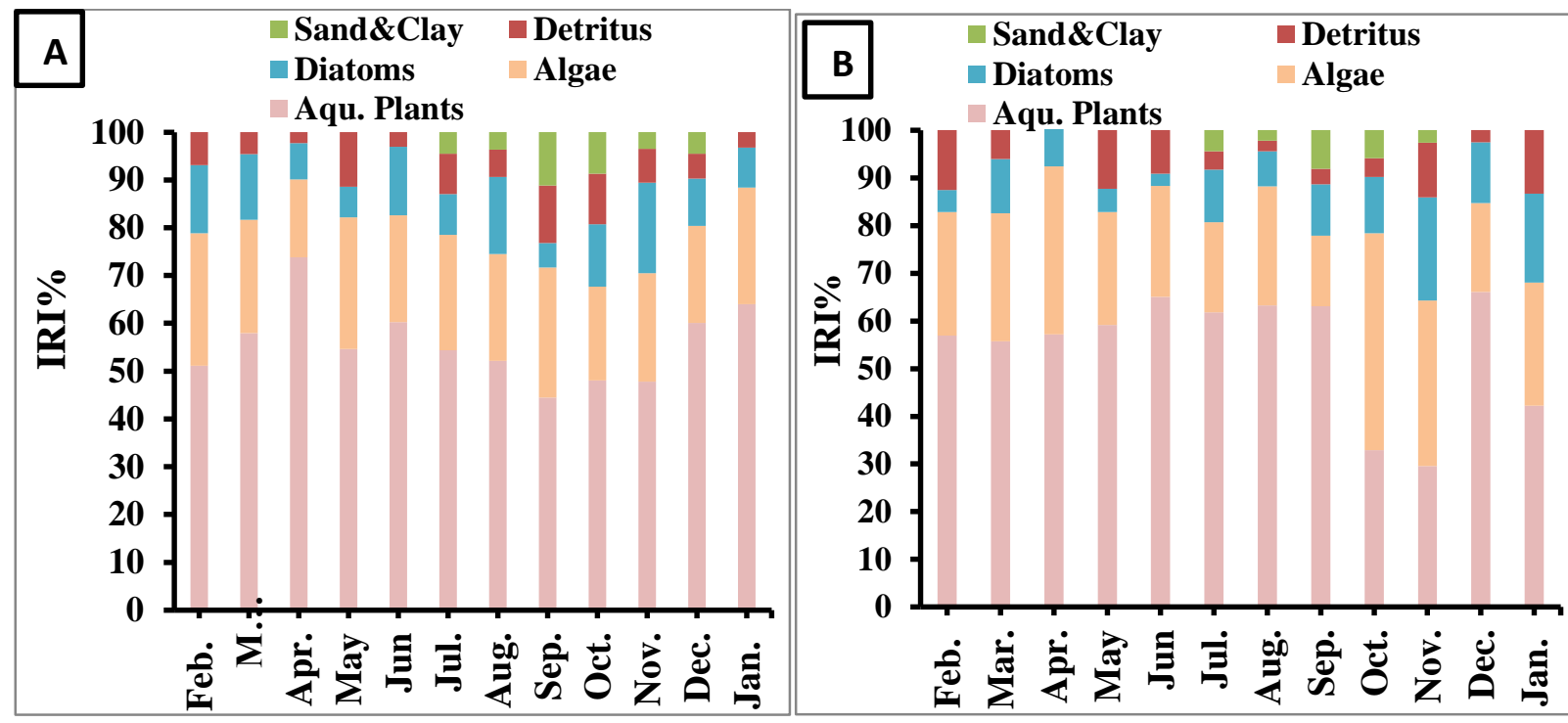

Fig. (3): Monthly changes in Index of relative importance (IRI) for small (A) and large $(B)$ individuals of Blue tilapia .

lowest in June. Organic detritus recorded low monthly percentage and the highest contribution was $13 \%$ in both January and February.

\section{Feeding activity and intensity}

Fig. (4 A) explained the monthly changes in the percentage of feeding activity for small and large individuals of Tigris asp. The percentage of small feeding activity was ranged from $25 \%$ in July to $92.31 \%$ in April and large individuals from $10 \%$ in December to $100 \%$ in March

Fig. (4 B) exhibited the monthly changes in the intensity of feeding for small and large individuals of Tigris asp. Which also differed between months. Their values ranged from 5 points / fish in November to 15 points / fish in May, and in large individuals 9.17 points /fish in January and 20 points / fish in October and December. 
Fig. (5A) represented monthly changes in the percentage of feed activity for small and large individuals of $\mathrm{Abu}$ mullet. Feeding activity for small individuals was ranged between $33.33 \%$ in June and $98.33 \%$ in April and large individuals from $32.08 \%$ in July and 95.10\% in April.

Fig. (5B) revealed monthly changes in the feeding intensity for small and large individuals of Abu mullet with the lowest intensity value of small individuals 5.18 points / fish in July and the highest in August (15 points / fish) and For large individuals its ranged between 5.29 points / fish during July and the highest in April 15.93 points / fish.

As well fig. (6A) showed monthly changes in the percentage of feeding activity for small and large individuals of Blue tilapia with the lowest percentage of small individuals reaching $35.29 \%$ in July and the highest of $96.30 \%$ in November, for large individuals ranging from $23.53 \%$ in August to $100 \%$ in April.
Fig. (6B) explained the monthly changes in the intensity of feeding for small and large individuals of Blue tilapia. The lowest intensity value of small individuals 7.71 points / fish in January and the highest in February and August (17.0 points /fish) while the lowest value for large individuals was 5.50 points / fish in September, the highest of 17.50 points / fish in October.

\section{Niche breadth}

Fig. (7) exhibited the niche breadth of the three studied species of fish with two groups of length. The three species of fish showed a different specialization in their selection for food components. The specialization of small Tigris asp was low (0.21) compared to higher specialization for large one (0.14). While for Abu mullet (0.33 and 0.31), and for Blue tilapia (0.22 and 0.23) for small and large individuals, respectively, which were generally less specialized than Tigris asp. In addition, no differences found between the two length groups of both later species.

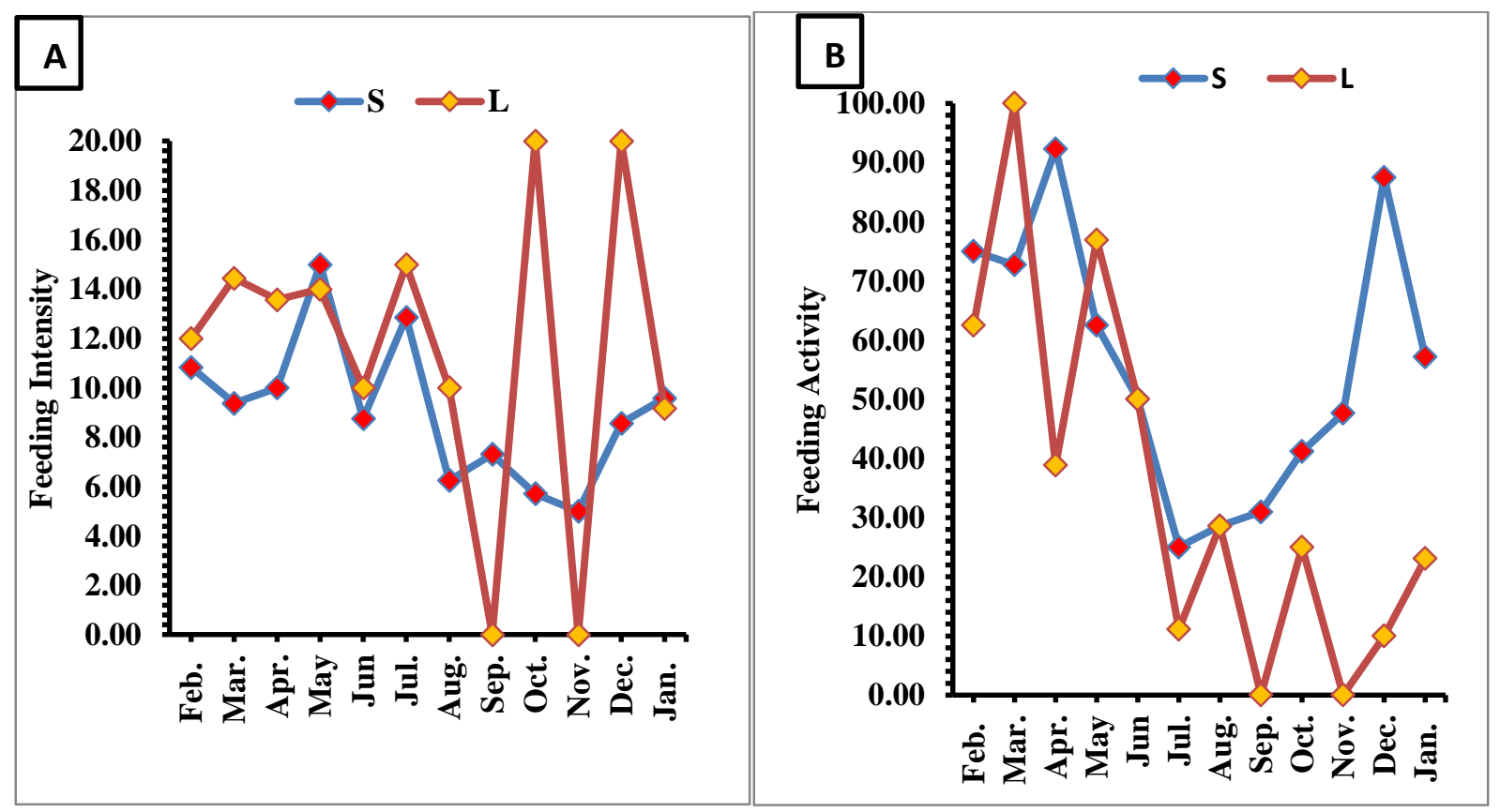

Fig. (4): Monthly changes in Feeding intensity (A) and activity (B) for small (S) and large (L) individuals of Tigris asp. 
Salih et al. / Basrah J. Agric. Sci., 32 (Special Issue): 140-152, 2019

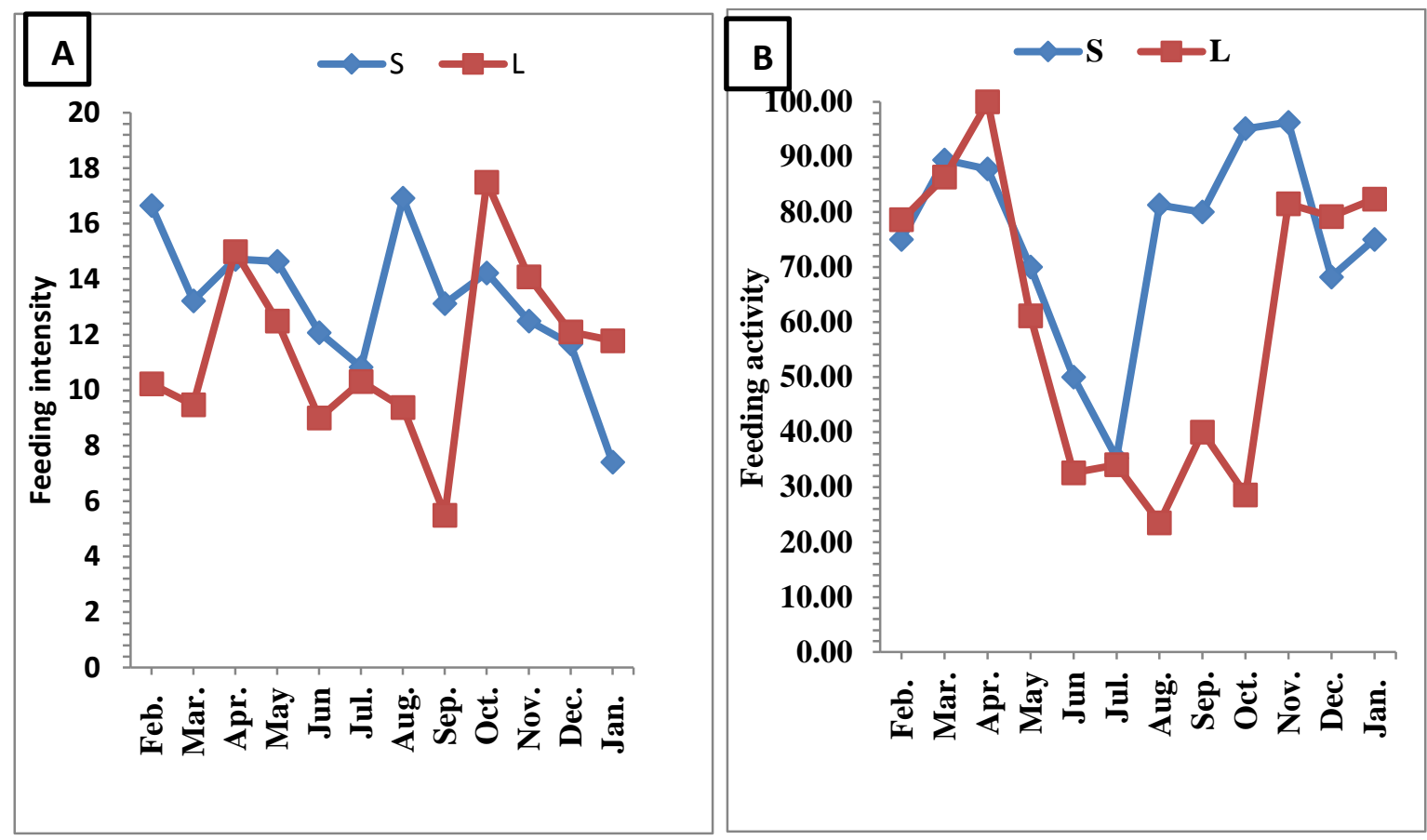

Fig. (5): Monthly changes in Feeding intensity (A) and activity (B) for small (S) and large (L) individuals of Abu mullet.

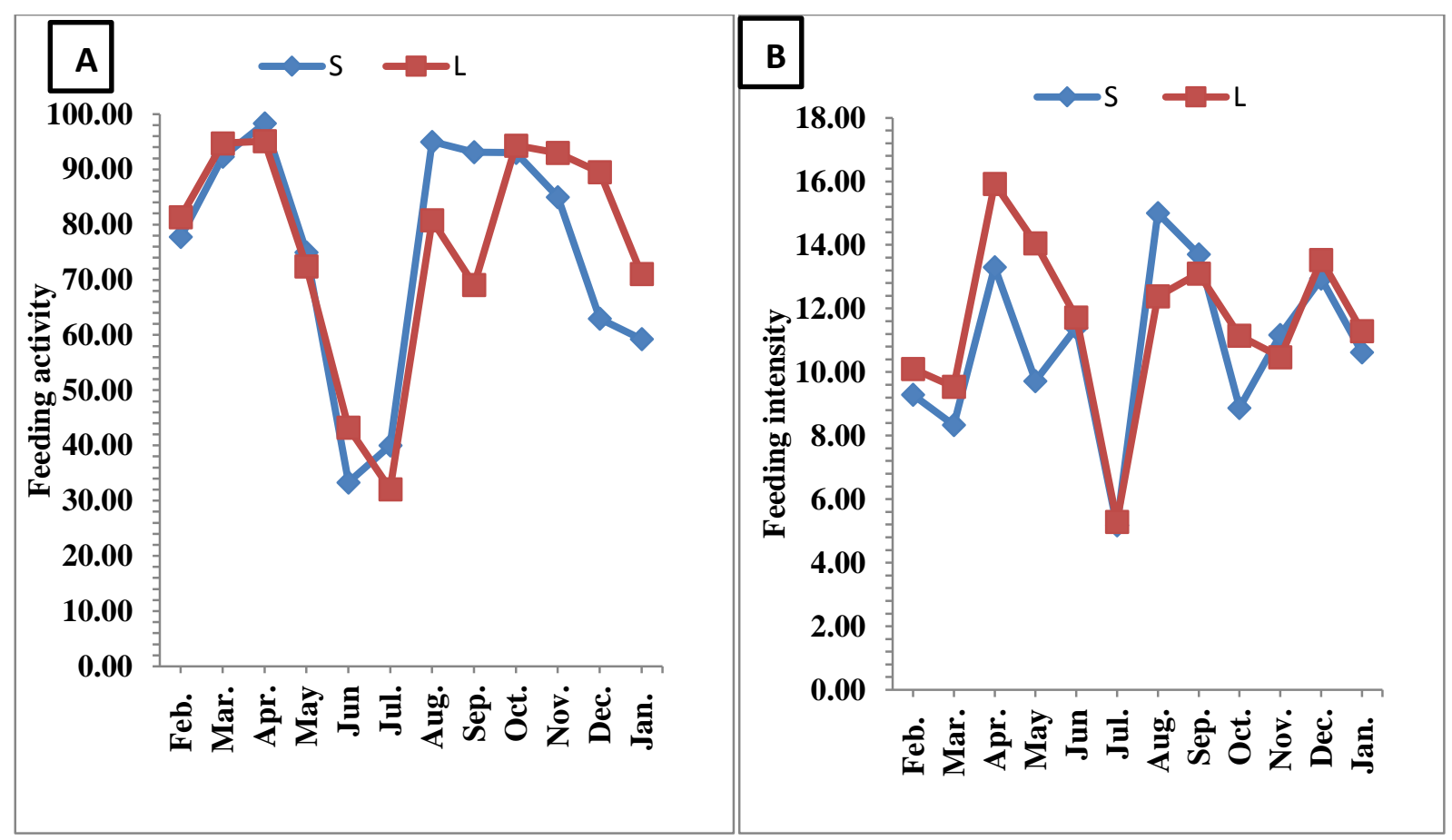

Fig. (6): Monthly changes in Feeding intensity (A) and activity (B) for small (S) and large (L) individuals of Blue tilapia. 
Salih et al. / Basrah J. Agric. Sci., 32 (Special Issue): 140-152, 2019

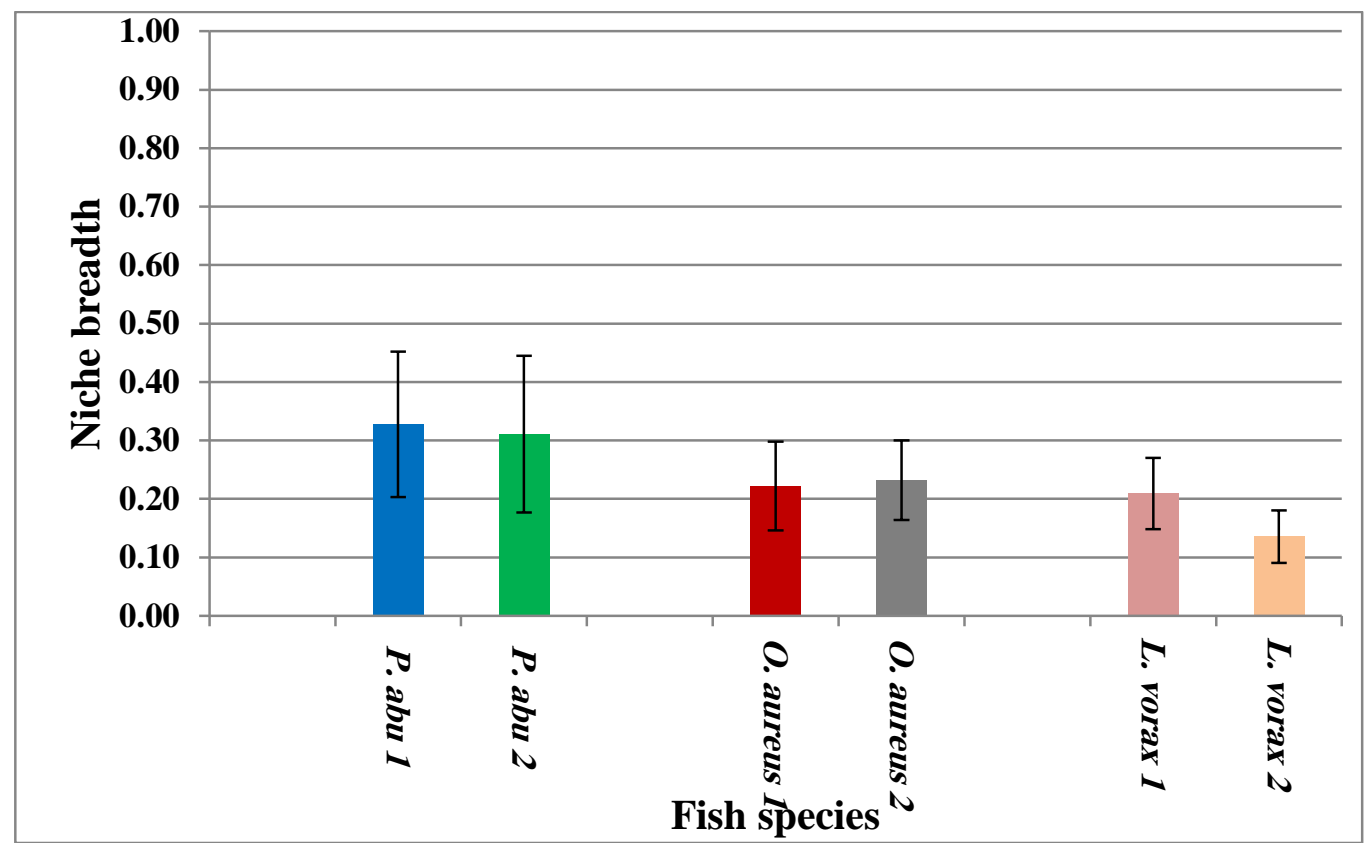

Fig.(7): Niche breadth of the three species (Tigris asp, Abu mullet and Blue tilapia) for small (1) and large (2) individuals.

\section{Discussion}

Studying feeding habits of fish in their natural environment is an important aspect of fish life; it not only recognizes the quality of food, it also helps us to identify feeding relationships with other organisms, it provide useful information on the trophic relationships in aquatic ecosystems (Abdel-Aziz \& Gharib, 2007). In addition, the difference in temperature from one season to another affects the nature and feeding intensity through its impact on food consumption rates, and on the quality and quantity of food available to fish species in the water surface in which they are present (Bhuiyan et al., 2006). The results of the food analysis showed that there was no difference in the components of small Tigris asp compared to large ones. The food of the two groups was composed from three main items in which the fish component was dominant. The food habits of the Tigris asp showed that they were carnivore's feedings and this was in accordance with Epler et al. (2009) where the animal component comprised more than $92 \%$ in Al- Habbaniyah Lake. Lazem (2009) found that fish ingredients accounted for $52.3 \%$ of the Tigris asp food in the Garmat Ali Canal as well as crustaceans $22.5 \%$ and insects $13.7 \%$, Mutlak (2012) pointed out that Tigris asp small individuals fed on seven items whereas large one fed on three items only comprised mainly of fish $(92.2 \%)$.

As to the relative importance index of small individuals of the Tigris asp , the fish accounted for $50 \%$, while $68 \%$ of the importance of food for large individuals this may be relate to its wide mouth, and the speed of catching prey ((Hussain et al., 2006; Mohamed et al., 2008; Hussain et al., 2009).

The results of the nature of $\mathrm{Abu}$ mullet food showed that it depend on five food components; this reflects the extent of the ability of this fish feeding. Fish consumed organic detritus, plants, algae and diatoms in all study months where it was concludes from the food contents that Abu mullet considered detritivore and bottom feeder. This agreed with other studies conducted in the AlChibayish (Hussain et al., 2006) and Hawizeh 
marshes (Mohamed et al., 2008). Wahab (1986) did not record zooplankton and snails in Abu mullet diet in Shatt al-Basrah Canal, while Al-Shawy \& Wahab (2008) found fish eggs in the Abu mullet food of the Tuz-Chi tributary. Shawardi (2006) consider Abu mullet omnivores since animal and plant items with plant component dominated in food in Al- Tharthar Lake and Tiger River. However Lazem (2009) considered it a detritivore in Garmat Ali channel because of the presence of organic and non-organic detritus in their food while their food include diatoms, algae, aquatic plants and protozoa as well as sand and clay granules in the east of Al-Hammar marshes (Mutlak, 2012). Diatoms were the dominant item in the gut of $\mathrm{Abu}$ mullet during the study of Mohamed \& Abood (2019).

The largest part of the food components of small and large individuals of the Blue tilapia consisted from aquatic plants. Additionally algae, diatoms and organic detritus were found in all year months while clay and sand appeared in some months only. Many studies have indicated that Blue tilapia considered herbivores, which agreed with the current study (Mallin, 1985; Noble, 1989). Al-Gamal (2006) indicated that Blue tilapia is a herbivores, omnivores or depend on large plants. Fish defined not by the nature of it feeds, but by the way or method of obtaining it. It is associated with the anatomical composition of the organs responsible for feeding. Blue tilapia have special characteristics of feeding method which can change the nature of feeding according to what is available in the environment, adding that the genus Oreochrmois is sometimes considered within the filter feeding fish. Aquatic plants accounted for $50 \%$ and $56 \%$ of the importance of the food of small and large individuals of Blue tilapia then algae of $23 \%$ and $26 \%$ followed by diatoms and detritus respectively, which is agreed with $\mathrm{Gu}$ et al. (1997).

The result showed that feeding intensity and activity similar in both length groups but differ monthly since metabolic rate increased with the water temperature rise (Hussein et al., 2003). Khalifa (2017) found that large individuals of Blue tilapia tend to depend on aquatic plants while small ones on algae. The three species as indicated from feeding intensity and activity were fed in all seasons but feeding intensity decline variably which agree with another previous studies (AlMukhtar, 1982; Shawardi, 2006; Wahab, 2006).

The results of the Levins index showed that the specialization of small Tigris asp was low while large individuals were highly specialized in their food selection, with the fish component accounting for $50 \%$ and $68 \%$ of their food respectively. This is in line with what Hussain et al (2009) mentioned. When studying the specialization of fish in the southern marshes, the majority of the studied species are specialized and the minority is the general feeder, whereas the Abu mullet and Blue tilapia considered narrow specialization since detritus and aquatic plants where the main food items respectively. The food specialization depends on the nature of food and the abundance of appropriate food (Mohamed et al., 2008). Taher (2010) recorded six highly specialized fishes (0$0.25)$, five low specialized species (0.26 - 0 . $40)$ and two general species $(0.50-1)$ when studying the specialization and food overlap of thirteen species of marine fish caught from the Shatt al-Basrah canal. Miller (2009) stated that fish that live in ponds are more specialized than open-water fish. 


\section{Conclusion}

The primary conclusion is that the three studied species are continuous feeders in all seasons depending on the most available natural food items in the studied area, but Tigris asp was more specialized than other two species that revealed carnivore's characterization.

Abdel-Aziz, ${ }_{2}$ N.E. \& Gharib, S.M. (2007). Food and feeding habits of round Sardinella (Sardinella aurita) in El- Mex Bay, Alexandria, Egypt. Egypt. J. Aquat. Res., 33: 202-221.

Al-Mukhtar, M.A. (1982).Biological studies on two fresh water species Barbus luteus (Heckel) and Aspius vorax (Heckel) in Al-Hammar marsh, Basrah. MSc. thesis, Science Collage, Basrah University, Iraq, 203 pp.

Ahmad, T.A. \& Hussian N.A. (1982). Observation on the food of young Liza abu (Heckel) from Salihyia River. Basrah Iraq. J. Mar. Sci., 1: 79-88.

Al-Malaika, I.S.; Sarsam, V.H. \& Ibrahim, A. (1977). The feeding biology of three phytoplankton feeding fish. $4^{\text {th }}$ Sci. Conf. Iraqi Biol. Soc. Baghdad, 20 $0^{\text {th }}-22$ th Sept. 1977.

Al-Shamma'a, A.A.; Al-Azawi, B.M. \& Shawardi, A.A. (2012). Food composition of Liza abu (Heckel, 1843) in Tigris River. Basrah J. Agric. Sci., 25(2): 254-264.

Al-Shawi S.A.S. \& Wahab N.K. (2008). Some biological aspects of Liza abu (Heckel) fish in TuzChi tributary, north Iraq. Samara J., 15: 214-228.

Bagenal, T.B. \& Tesch, F.W. (1978). Age and growth. Pp: 101-103. In: Bagenal, T.B. (Ed.). Methods for assessment of fish production in fresh water. $3^{\text {rd }}$ ed. Blackwell Sci. Publ. Oxford: 300pp.

Barak, N.A. (1978). Food habits of three Iraqi fishes, Aphanius dispar (Ruppll), Liza abu (Heckel) and Alburnus mossulensis (Heckel) in Al-Sakliwah irrigation drainage system. M. Sc. Thesis, Univ. Baghdad: 147pp.

Bhuiyan, A.S.; Afroz, S. \& Zaman, T. (2006). Food and feeding habit of the juvenile and adult Snakehead, Channa punctatus (Bloch). J. Life Earth Sci., 1(2): 53-54.

Birecikligil, S.; Secer, B.; Kellecl, M.; Aras, E. \& Cicek, E. (2017). Determination of some population dynamical parameters of Planiliza abu (Heckel, 1843), from Ceyhan River basin. Acta Aquatica Turcica, 13(1): 58-65.

Coad, B.W. (2017). Review of the Freshwater Mullets of Iran (Family Mugilidae). Iran. J. Ichthyol., 4(2): 75-130.

Duman, E \& Gül, M.R. (2013). Age, growth, fecundity and mortality of Aspius vorax (Heckel, 1843) in Karakaya Reservoir (in Euphrates River), Turkey. Ege. J. Fish. Aqua. Sci., 30(4): 155159.

Epler, P.; Bartel, R.; Chyp, J. \& Szczerbowski, J.A. (2001). Diet to selected fish species from the Iraqi Lakes Tharthar, Habbaniya and Razzazah. Arch. Pol. Fish., 9: 211-223.

Gordan, J.D. (1977). The fish population in the store water of west coast Satl and the food and feeding of whiting Merlangui merlangiu. J. Fish Boil., 11(6): 512-529. 
Gysels, E.; Bisthoven, L.J.; Vos, L. \& Ollevier, F. (1997). Food and habitat of four Xenotilapia species (Teleostei, Cichlidae) in a sandy bay of northern Lake Tanganyika (Burundi). J. Fish Biol., 50(2): 254- 266.

Gu, B.H.; Schelske, C. \& Hoyer, M.V. (1997). Intrapopulation feeding diversity in blue tilapia: Evidence from stable-isotope analyses. Ecology, 78(7): 2263-2266.

Hurlbert, S.H. (1978). The measurement of niche overlap and some relatives. Ecology, 59: 67-77.

Hurst, T.P. \& Conover, D.O. (2001). Diet and consumption rates of overwintering YOY striped bass, Morone saxatilis, in the Hudson River. Fish. Bull., 99(4): 545-553.

Hansson, S. (1998). Methods of studying fish feeding: A commet. Can. J. Fish. Aquat. Sci., 55: 2706-2707.

Hussain, N.A. \& Ali, T.S. (2006). Trophic nature and feeding relationships among Al-Hammer Marsh fishes, Southern Iraq. J. Marsh Bull., 1(1): 9-18.

Hussain, N.A.; Saoud, H.A. \& Al-Shami, E.J. (2009). Specialization, competition and diet overlap of fish assemblages in the recently restored Southern Iraqi. J. Marsh Bull., 4(1): 21-35.

Hussein, S.A. \& Al-Kanaani, S.M. (1993). Feeding ecology of the shilig Aspius vorax Heckel from Al-Hammar marsh, southern Iraq III. Seasonal pattern of feeding. Mar. Mesopot., 8(1): 91-103.

Hussein, S.A.; Al-Daham, N.K. \& Al-Kanaani, S.M. (1991). Selection of benthic mollusca and macrocrustacean and their importance in the diet of three sympatric fish species in Garma marshes, Iraq. Mar. Mesopt., 6: 263-280.

Hussein, S.A.; Al-Daham, N.K. \& Al-Dubaikel, A.Y. (2003). Satiation time, appetite and food intake in fingerlings of three freshwater fishes (i.e. Barbus sharpeyi; B. xanthopterus and Cyprinus carpio L.) under artificial conditions. J. Basrah Res., 29: 41-47.

Hussain, N.A. \& Ali, T.S. (2006). Trophic nature and feeding relationships among Al Hammer marsh fishes, Southern Iraq. Marsh Bull., 1(1): 9-18.

Hyslop, E.J. (1980). Stomach contents analysis -a review of method and their application. J. Fish Biol., 17: 413-422.

Islam, A.K.M.S. \& Khalaf, A.N. (1982). Diel patterns of feeding of Khishni Liza abu (Heckel) in Rashdiyah Reservoir in Baghdad, Iraq. Indian J. Fish., New Delhi. 29(1 \& 2): 223-228.

Jutagate, T.; Krudpan, C.; Ngamsnae, P.; Lamkom, T. \& Payooha K. (2005). Changes in the fish catches during a trial opening of sluice gates on a run-of-the river reservoir in Thailand. Fish. Manag. Ecol., 12: 57- 62.

Khalifa, S.Z. (2017). Ecological and biological of Nile tilapia Oreochromis niloticus and blue tilapia Oreochromis aureus from Tigris River Southern Baghdad. M. Sc. Thesis. Univ. Diyala: 138 pp.

Krebs, C.J. (1999). Ecological Methodology. Harper and Row, New York: 620pp.

Lazem L.F. (2009). Ecological evaluation of the Shatt Al-Arab river by applying geographical information system (GIS). Ph. D. Thesis, Univ. Basrah: 134pp..

Liem, K. (1984). Functional versatility, speciation and niche-overlap: are fishes different? In Trophic Interactions within aquatic ecosystems, Pp: 269-305 In Meyers, D.G. \& Strickler, J.R. (Eds.). AAAS Selected Symposium, 85. Boulder, Colorado. Westview Press: 472pp.

Mallin, M.A. (1985). The feeding ecology of the blue tilapia (Tilapia aurea) in North Carolina reservoir. Proc. Conf. Int. Symp. Appl. Lake Watershed Manage., 5: 323- 326. 
Miller, B.A. (2009). Effects of physicochemical properties and macrohabitat on the foraging ecology and condition of the centrarchid assemblage of the Atchafalaya River Basin, Louisiana. M. Sc. Thesis . Univ. Louisiana: 113pp.

Mohamed, A.R.M. \& Abood, A.N. (2019). Food and trophic relationships of four mullet fish (Mugilidae) in the Shatt Al-Arab River, Iraq. Asian J. Appl. Sci., 7(1): 19-26.

Mohamed, A.R.M.; Hussain, N.A.; Al-Noor, S.S.; Coad, B.W.; Mutlak, F.M.; Al-Sudani, I.M.; Mojer, A.M. \& Toman, A.J. (2008). Species composition, ecological indices and trophic pyramid of fish assemblage of the restored Al-Hawizeh Marsh, Southern Iraq. Ecohydrol. Hydrobiol., 8(2- 4): 375-384.

Mutlak, F.M. (2012). Stock assessment of some fish species in east Hammar marsh. Ph.D. Thesis Basrah Univ.: 193pp.

Mutlak, F.M. \& Al-Faisal, A.J. (2009). A new record of two exotic cichlids fish Oreochromis aureus (Steindacher, 1864) and Tilapia zilli (sic) (Gervais, 1848) from south of the main outfall drain in Basrah city. Mesopot. J. Mar. Sci., 24(2): 160-170.

Naama, A.K. \& Muhsen, K.A. (1986). Feeding periodicities (sic) of the mugilid Liza abu (Heckel) and cyprinid Carasobarbus luteus (Heckel) from Al-Hammar Marsh, southern Iraq. Indian J. Fish., 33: 347-350.

Noble, R.L. (1989). Biological control for aquatic weeds using fish. Water Resources Research Institute. Proc. workshop on management of aquatic weeds and mosquitoes in impoundment Charlotte, N.C., 247: 83-87.

Novakowski, G.C.; Hahn, N.S. \& Fugi, R. (2008). Diet seasonality and food overlap of the fish assemblage in a Pantanal pond. Neotr. Ichth., 6(4):567-576.

Shawardi, A.A. (2006). Ecology and biology of Carassius carassius (L.1758) and Liza abu (Heckel, 1843) in Tharthar Lake and Tigris River. Ph. D Thesis: Univ. Al-Mustansiria: 142pp.

Stergiou, K.I. (1988). Feeding habits of the lessepsian migrant Siganus luridus in the Eastern Mediterranean, its new environment. J. Fish Biol., 33: 531-543.

Taher, M.M. (2010). Specialization, trophic breadth and diet overlap of thirteen small marine fish species from Shatt Al-Basrah Canal, Southern Iraq. Marsh Bull., 5(2):118-130.

Wahab, N.K. (1986). Ecology and biology of three species of mugilid fishes in Shatt Al-Basrah Canal. M. Sc. Thesis. Univ. Basrah: 155pp. 